\title{
APLIKASI MUDHARABAH DALAM PERBANKAN SYARIAH DI INDONESIA
}

\author{
Sri Abidah Suryaningsih \\ Fakultas Ekonomi Universitas Negeri Surabaya \\ E-mail: abidah.mustofa@gmail.com
}

\begin{abstract}
This theory analysis article aims to describe the meaning of mudharabah, explain about Sharia banks, and provide an overview on implementation of mudharabah in Islamic banking in Indonesia. Mudharabah takes place when there are investor (Shahibul mall), fund manager (mudharib), business activity, and profit sharing proportion (nisbah) agreement between investor and manager. Sharia banking should be performed based on some characteristics, specifically: usury (riba)-free, provides public services and realizes the socio-economic goals of Islam, universal, and applies profit and loss sharing. Moreover, mudharabah application in Islamic banking in Indonesia has the following characteristics: transactions must be intended to financing, business management is entrusted to mudhorib, and profits sharing system must be based on the principle of revenue sharing and proportion of profit sharing are subject to change during the term of the contract as agreed in the initial contract.
\end{abstract}

Keywords: Mudharabah, Sharia Bank

\begin{abstract}
Abstrak
Tujuan dari artikel untuk mendiskripsikan makna akad mudharabah, makna bank syari'ah dan aplikasi mudharabah dalam perbankan syariah di Indonesia. Artikel merupakan analisis kajian teori. Dapat disimpulkan bahwa Akad mudharabah terjadi jika ada pihak shahibul mal, ada mudharib, ada obyek yang dikerjakan, dan ada kesepakatan nisbah antara pihak pemilik modal dengan pengelola.Perbankan syari'ah memiliki ciri-ciri: bebas riba, pelayanan kepada kepentingan publik dan merealisasikan sasaran sosio-ekonomi Islam, bersifat universal, dan penerapan bagi hasil tanpa adanya unsur pemaksaan. Sedangkan aplikasi mudharabah dalam perbankan syariah di Indonesia memiliki karakteristik sebagai berikut: tujuan transaksi untuk pembiayaan, pengelola usaha adalah mudharib, pembagian hasil mengacu pada konsep revenue sharing, dan penentuan nisbah bagi hasil dapat berubah selama periode perjanjian dan ditetapkan pada akad di awal periode kontrak.
\end{abstract}

Kata kunci: Mudharabah, Bank Syariah

Ajaran agama terkait perilaku manusia diungkapkan secara jelas dalam berbagai kitab suci. Agama Islam melalui sumber hukum utamanya yaitu Al-Qur'an dan Al- hadist memberikan ajaran konkrit bagaimana manusia berinteraksi dengan Tuhan atau Hablun min Allah dan bagaimana manusia beriteraksi sesama manusia atau 
Hablun Min Annas. Aturan-aturan suci melalui firman Allah dan Sunnah Rasul tidak sekedar dibaca dan direnungkan namun sudah menjadi kewajiban bagi manusia beragama untuk menerapkan ajaran agama dalam kehidupan sehari-hari.

Islam adalah agama komprehensif agama yang secara konkrit mengatur urusan dunia dan juga mengatur urusan akhirat. Manusia secara lahiriyah disibukkan dengan urusan duniawi dan secara batiniyah di sibukkan dengan urusan ukhrawi. Dunia dan akhirat adalah dua hal yang tidak bisa terpisahkan dalam hidup artinya segala aktivitas manusia harus berparadigma dunia dan akhirat. Kesadaran akan tanggung jawab utuh melahirkan manusia bijaksana.

Interaksi sesama manusia dengan diniatkan beribadah kepada Allah tercermin dalam bidang muamalah. Sebagaimana pendapat Quraish Shihab (2007) aktivitas antar sesama manusia termasuk aktivitas bidang ekonomi disitilahkan oleh para ulama dengan istilah mu'amalah atau yang berarti interaksi. Perilaku manusia dalam bidang ekonomi tentunya harus berdasar pada aturan-aturan yang dibenarkan dalam Islam dan menghindarkan aktivitas yang dilarang dalam agama, Al-qur' an menjelaskan dalam surat Al-Baqarah ayat 188:

Artinya:

"dan janganlah sebahagian kamu memakan harta sebahagian yang lain di antara kamu dengan jalan yang bathil ...”

Beberapa prinsip-prinsip syariah yang mendasari kegiatan perekonomian berbasis Islam antara lain Mudharabah, Musyarakah, Murabahah, Kafalah, Wakalah, Wadi' ah, Ijarah, dll. Kajian fiqh muamalah menjadi dasar keilmuan dalam praktik kegiatan ekonomi. Seperti pada perbankan syariah, secara operasional perbankan syariah sering menggunakan mudharabah baik dalam rangka menghimpun dana dari kalangan masyarakat dan juga digunakan untuk menyalurkan dana kepada masyarakat (Haidar, 2011).

Pemahaman teori fiqh muamalah di kalangan masyarakat umum masih memerlukan sosialisasi lebih optimal, misalnya pemahaman tentang teori mudharabah jika diterapkan dalam perbankan. Minimnya pemahaman masyarakat muslim terhadap istilah fiqh pada perbankan syariah pernah diungkap oleh Philip Gerrard dalam penelitiannya dengan judul Islamic banking: a Study in Singapore dengan sampel 29 warga mus$\mathrm{lim}$. Hasil penelitian menunjukkan $20.7 \%$ memahami makna riba, $31 \%$ memahami syariah. Dalam konteks keuangan Islam menunjukkan tidak seorangpun paham murabaha dan hanya 1 responden yang mampu mendiskripsikan Ijarah, Mudharabah dan musharakah. Sedangkan di kalangan masyarakat non muslim dengan responden 161 , $0.6 \%$ memahami riba dan $2 \%$ memahami syariah. Sedangkan dalam konteks keuangan Islam tidak satupun responden yang memahaminya.

Seiring dengan perkembangan waktu praktik muamalah semakin banyak dikembangkan pada lembaga keuangan syariah termasuk negara Indonesia. Perkembangan perbankan syariah di Indonesia begitu cepat dan pesat, namun di sisi lain masih ada sebagian masyarakat masih memiliki asumsi bahwa bank syariah hanya sebuah label untuk menarik simpati masyarakat muslim di bidang perbankan, sebagian masyarakat menganggap tidak ada perbedaan antara perbankan syariah dengan perbankan konvensional, yang membedakan hanya istilah-istilah dalam bahasa arab yang digunakan pada perbankan syariah. (Hulam, 
Aplikasi Mudharabah dalamPerbankan Syariah di Indonesia (Sri Abidah Suryaningsih)

2010). Asumsi tersebut berkembang salah satu sebabnya adalah belum maksimalnya pemahaman masyarakat muslim Indonesia terhadap makna akad yang digunakan pada perbankan syariah.

Salah satu akad dalam fiqh muamalah yang digunakan dalam perbankan syari' ah di Indonesia adalah akad mudharabah. Tulisan ini bertujuan memberikan gambaran secara utuh akan makna akad mudharabah, makna bank syari' ah dan bagaimana aplikasi mudharabah dalam perbankan syariah di Indonesia.

\section{Akad Mudharabah}

Kerja sama dalam bidang usaha sejak zaman Rasulullah sudah pernah dipraktikkan, Rasulullah pernah dipercaya oleh Khadijah untuk menjalankan bisnis perdagangan dengan akad kerjasama, akad yang dijalankan antara pemilik modal dengan yang menjalankan modal. Khadijah sebagai pemilik modal menyerahkan kepercayaan penuh kepada Rasulullah untuk menjalankan usaha. Akad kerjasama seperti ini dalam ilmu fiqh dinamakan akad Mudharabah.

Mudharabah menurut Iska (2012:184) secara etimologis berasal dari bahasa Arab الأرض فى الضرب yang bermakna "pergi untuk urusan dagang" sebagaimana firman Allah SWT dalam surat Al-Muzzammil : 20, "dan orang-orang yang berjalan di muka bumi mencari sebagian karunia Allah”. Sedangkan mudharabah secara istilah akad kerjasama antara dua pihak atau lebih, ada satu pihak yang memiliki modal atau dalam bahasa fiqih disebut Shahibul mal sedangkan pihak yang lain sebagai pelaksana usaha atau Mudharib. Akad kerjasama mudharabah secara detail dijelaskan bahwa akad yang tejalin antara pihak pertama
(Shahibul mal) dengan menyediakan modal $100 \%$ dengan pihak yang lain sebagai pengelola (Mudharib), sedangkan pembagian keuntungan berdasarkan kesepakatan bersama. Apabila terjadi kerugian yang bukan karena kelalaian pihak pengelola maka yang menanggung adalah pihak pemilik modal.

Akad mudharabah menjadi sah menurut syariah Islam jika memenuhi beberapa rukun dan syarat. Rukun mudharabah (Karim, 2011:205) yaitu: 1) Pelaku/pemilik modal atau pelaksana usaha, akad mudharabah terjadi jika ada minimal dua pelaku yaitu shahibul mal dan mudharib; 2) Objek mudharabah / modal dan kerja, adanya modal dan usaha merupakan konsekuensi dari jalinan kerjasama, shahibul mal menyediakan keseluruhan dana sedangkan mudharib menggunakan modal untuk menjalankan usaha; 3) Persetujuan kedua belah pihak / ijab-qabul, pihak shahibul mal dan mudharib mensepakati akad kerjasama. dan 4) nisbah keuntungan, berbentuk prosentase misalnya 70:30, 60:40 tidak dinyatakan dalam nilai nominal tertentu dan nisbah keuntungan ditentukan berdasarkan kesepakatan antara shahibul mal dan mudharib.

Adapun syarat-syarat dalam akad mudharabah menurut Iska (2012:187) yaitu: 1) modal yang dikeluarkan shahibul mal dalam bentuk tunai, 2) diketahui dengan pasti antara modal awal dengan hasil keuntungan, 3) adanya kejelasan dalam akad dalam hal pembagian keuntungan, 4) pelaksanaannya bersifat mutlak, shahibul mal tidak membatasi misalnya waktu kapan mudharib harus menyelesaikan usahanya.

Menurut pasal 231 kompilasi hukum ekonomi syariah dalam Mardani (2012 :198) syarat mudharabah, adalah sebagai berikut: 1) pemilik modal atau shahibul mal wajib menyerahkan dana atau barang yang 
bernilai kepada pihak lain untuk melakukan kerjasama dalam usaha. 2) penerima modal atau mudharib menjalankan usaha dalam bidang yang disepakati. 3) kesepakatan bidang usaha yang akan dilakukan ditetapkan dalam akad. Transaksi dengan menggunakan akad mudharabah menghadirkan dua pihak atau lebih untuk melakukan kerjasama dengan mengutamakan kesepakatan berdasarkan rukun dan syarat yang diketahui dan disepakati bersama.

Di sisi lain mudharabah dibagi menjadi dua jenis, yaitu 1) mudharabah muthlaqah, yaitu akad kerjasama antara shahibul mal dan mudharib bersifat mutlak tanpa adanya pembatasan spesifikasi jenis usaha, waktu, dan daerah bisnis. dan 2) mudharabah muqayyadah, jenis mudharabah ini kebalikan dari mudharabah muthlaqah, shahibul mal membatasi jenis usaha, waktu atau tempat usaha.

Ketentuan mudharabah menurut kompilasi hukum ekonomi syariah adalah antara lain sebagai berikut (Mardani: 200): Pasal 238: 1) status benda yang berada di tangan mudharib yang diterima dari shahibul mal adalah modal, 2) mudharib berkedudukan sebagai wakil shahib al-mal dalam menggunakan modal yang diterimanya, 3) keuntungan yang dihasilkan dalam mudharabah menjadi milik bersama. Pasal 239: 1) mudharib berhak membeli barang yang dengan maksud menjualnya kembali untuk memperoleh untung, 2) mudharib berhak menjual dengan harga tinggi atau rendah baik dengan tunai atau non tunai, 3) mudharib berhak menerima pembayaran dari harga barang dengan pengalihan piutang, 4) mudharib tidak boleh menjual barang dalam jangka waktu yang tidak biasa dilakukan oleh para pedagang.

Ketentuan yang lain ada dalam pasal 240: mudharib tidak boleh menghibahkan, meyedekahkan, dan atau meminjamkan harta kerjasama, kecuali bila mendapat izin dari pemilik modal. Pasal 241: 1) mudharib berhak memberi kuasa kepada pihak lain untuk bertindak sebagai wakilnya untuk membeli dan menjual barang jika telah disepakati dalam akad mudharabah, 2) mudharib berhak menginvestasikan harta kerjasama dengan sistem syariah, 3) mudharib berhak menghubungi pihak lain untuk melakukan jual beli barang sesuai kesepakatan dalam akad. Pasal 242: 1) mudharib berhak atas keuntungan sebagai imbalan pekerjaannya yang disepakati dalamakad, 2) mudharib tidak berhak mendapatkan imbalan jika usaha yang dilakukan rugi. Pasal 243: 1) pemilik modal berhak atas keuntungan berdasarkan modalnya yang disepakati dalam akad, 2) pemilik modal tidak berhak mendapatkan keuntungan jika usaha yang dilakukan oleh mudharib merugi.

Pasal yang lain pasal 252: kerugian usaha dan kerusakan barang dagangan dalam kerja sama mudharabah yang terjadi bukan karena kelalaian mudharib, dibebankan pada pemilik modal. Pasal 253: akad mudharabah berakhir dengan sendirinya jika pemilik modal meninggal dunia, atau tidak cakap melakukan perbuatan hukum. Pasal 254: 1) pemilik modal berhak melakukan penagihan terhadap pihak-pihak lain berdasarkan bukti dari mudharib yang telah meninggal dunia, 2) kerugian yang diakibatkan oleh meninggalnya mudharib, dibebankan pada pemilik modal.

Akad mudharabah menjadi batal apabila ada beberapa perkara sebagai berikut: 1) tidak terpenuhinya salah satu syarat mudharabah, 2) pengelola dengan sengaja meninggalkan tugasnya atau bertentangan dengan tujuan akad sebagai pengelola modal maka harus bertanggungjawab jika terjadi kerugian karena mudharib menjadi penye- 
Aplikasi Mudharabah dalamPerbankan Syariah di Indonesia (Sri Abidah Suryaningsih)

bab kerugian, 3) apabila pelaksana atau pemilik modal meninggal dunia, akad mudharabah menjadi batal. Perkara tersebut menjadi penyebab akad mudharabah tidak bisa dilanjutkan walaupun sebelumnya sudah disepakati antara pihak shahibul mal denganmudharib.

Akad mudharabah mempunyai dasar hukum Al-Qur'an dan As-sunnah sebagaimana di fatwakan oleh Dewan Syariah Nasional Majlis Ulama Islam(Mardani, 2012:204) Dasar hukum bersumber dari firman Allah SWT surat an-Nisa' ayat 29: "Hai orangorang yang beriman, janganlah kamu saling memakan harta sesamamu dengan jalan yang batil, kecuali dengan jalan perniagaan yang Berlaku dengan suka sama-suka di antara kamu..."

Firman Allah SWT.dalam QS. AlMaidah :1

"Hai orang-orang yang beriman, penuhilah aqad-aqad itu..."

Firman Allah SWT dalam QS. AlBaqarah:283

“...jika sebagian kamu mempercayai sebagian yang lain, Maka hendaklah yang dipercayai itu menunaikan amanatnya (hutangnya) dan hendaklah ia bertakwa kepada Allah Tuhannya..."

Dasar hukum mudharabah dari alHadist antara lain yang diriwayatkan oleh Ibnu Majah dari Shuhaib:

"Nabi bersabda, ada tiga hal yang mengandung berkah: jual beli tidak secara tunai, mudharabah, dan mencampur gandum dengan jewawut untuk keperluan rumah tangga, bukan untuk dijual"

Hadist lain diriwayatkan oleh Thabrani:

"Abbas bin Abdul Muthalib jika menyerahkan harta sebagai mudharabah, ia mensyaratkan kepada mudharib-nya agar tidak mengarungi lautan dan tidak menuruni lembah, serta tidak membeli hewan ternak. Jika persyaratan itu dilanggar, ia (mudharib) harus menanggung resikonya. Ketika persyaratan yang ditetapkan Abbas itu didengar Rasulullah, beliau membenarkannya"

Sedangkan sumber hukum dari ijma' atau kesepakatan para ulama: "diriwayatkan, sejumlah sahabat menyerahkan (kepada orang, muidharib) harta anak yatim sebagai mudharabah dan tidak ada seorangpun mengingkari mereka. Karenanya, hal itu dipandang sebagai ijma'.

Transaksi mudharabah diqiyaskan kepada transaksi musaqoh atau muzara'ah yaitu si penggarap hanya bertanggung jawab atas pemeliharaan sebagai imbalan dan berhak atas nisbah tertentu dari hasil panen. Transaksi mudharabah juga diperbolehkan berdasarkan kaidah fiqh:

"Pada dasarnya, semua bentuk muamalah boleh dilakukan kecuali ada dalil yang mengharamkannya".

Semua bentuk muamalah pada awalnya diperbolehkan dalam syariah Islam selama tidak ditemukan dalil yang memberatkan atau melarangnya.

Beberapa dasar hukum tersebut mendasari diperbolehkannya melakukan kerjasama dengan menggunakan akad mudharabah. Adanya hukum diperbolehkannya kerjasama melalui akad mudharabah memberikan kejelasan sekaligus memberikan solusi bagi para pemilik modal yang tidak mempunyai kemampuan mengoperasionalkan usaha diperbolehkan menjalin kerjasama dengan seseorang yang tidak memiliki modal namun mempunyai kemampuan untuk menjalankan usaha.

Bentuk-bentuk akad mudharabah antara lain: 1) mudharabah bilateral atau sederhana, akad kerjasama antara pemilik modal (shahibul mal) dengan pihak yang men- 
jalankan usaha (mudharib) seperti shahibul mal menyerahkan seluruh modal kepada mudharib dengan perjanjian bagi hasil yang telah disepakatimisalnya 40:60, keuntungan $40 \%$ untuk shahibul mal dan $60 \%$ untuk mudharib. 2) Mudharabah multilateral yaitu akad mudharabah antara beberapa pemilik modal atau shabul mal dengan satu pihak pengelola atau mudharib, seperti pemilik modal satu dan pemilik modal dua menyerahkan modal dana kepada pengelola dengan kesepakatan bagi hasil antara ketiga belah pihak misalnya membagi prosentase keuntungan 70:30. 70\% dibagi antara pemilik modal 1 dan pemilik modal 2. 3) Mudharabah bertingkat (Re-mudharabah), bentuk akad mudharabah antara shahibul mal dengan dua mudharib yaitu mudharib antara dengan mudharib akhir. Kemitraan yang dibangun dengan menyepakati bagi hasil keuntungan misalnya dengan mudharib antara 70:30 dan dengan mudharib akhir 60:40. 4) kombinasi Musharakah dan $\mathrm{Mu}-$ dharabah, yaitu akad terjadi antara shabul mal dengan mudharib, mudharib diberi kesempatan berinvestasi selama proses usaha berlangsung dan pihak mudharib berhak mendapatkan nisbah bagi hasil dari modal yang diinvestasikan. (Ascarya, 2011:68-74)

Ketentuan kerjasama dengan menggunakan akad mudharabah terjalin dengan mengedepankan unsur saling percaya, jujur, dan kerelaan antara pihak penyedia modal dengan pengelola modal. Kesepakatan antara shahibul mal dan mudharib terjadi bukan karena unsur keterpaksaan, unsur kekeluargaan lebih diutamakan tetapi bukan berarti mengindahkan aturan-aturan, syarat dan rukun yang telah diketahui dan disepakati bersama. Misalnya jika terjadi kelalaian dari pihak mudharib maka pihak pengelola sepenuhnya harus menanggung segala bentuk kerugian.

\section{Bank Syari'ah}

Perkembangan perbankan di dunia menunjukkan kemajuan positif di pasar ekonomi, respon nasabah terhadap jasa perbankan sangat tinggi. Ada dua jenis perbankan yang beroperasi di tengahtengah masyarakat yaitu perbankan konvensional dan perbankan syari'ah. Perbedaan yang mendasar antara kedua jenis bank tersebut terletak pada penetuan harga jual dan harga beli, perbankan konvensional penentuan harga selalu didasarkan pada bunga sedangkan perbankan syari'ah didasarkan pada konsep Islam yaitu nisbah pembagian bagi hasil baik untung dan rugi. (Kasmir, 2013:166)

Perbankan syariah pertama praktik dilaksanakan sejak masa awal Islam pada tahun 1963 oleh Dr. Abdul Hamid an-Naggar. Kemudian pada tahun 1975 diadakan konferensi Ekonomi Islam di Mekkah yang melahirkan IDB Islamic Development Bank yang diikuti dengan pembentukan lembagalembaga keuangan Islam di berbagai negara. Di Indonesia perkembangan perbankan syariah dimulai pada tahun 1980 dengan gagasan konsep lembaga keuangan syariah dengan uji coba BMT Salman di Bandung dan pekoperasi Ridho Gusti. Pada tahun 2008 pada tanggal 16 Juli atau pada UU No. 21 perbankan syariah disahkan dengan memberikan landasan hukum industri perbankan syariah nasional dan diharapkan mendorong perkembangan bank syariah yang selama lima tahun terakhir asetnya tumbuh lebih dari $65 \%$ per tahun namun pasarnya (market share) secara nasional di bawah 5\%. (Soemitra, 2009:63)

Berdasarkan data IB Indonesia, perkembangan perbankan syariah pada akhir tahun 2012 menunjukkan data yang menggembirakan, perbankan syariah mampu tumbuh $37 \%$ total aset Rp. 174,09 triliun, 
Aplikasi Mudharabah dalamPerbankan Syariah di Indonesia (Sri Abidah Suryaningsih)

pembiayaan mencapai Rp. 135,58 triliun (40,06\%) dan penghimpunan dana menjadi Rp. 134,45 triliun (32,06\%). Perbankan syariah menggunakan stratregi edukasi dan sosialisai bersama Bank Indonesia dan industri dalam bentuk IB campaign untuk proses funding danfinancing. Hal ini mampu memperbesar market share perbankan syariah yaitu $\pm 4,3 \%$. Penghimpunan dana terbesar berasal dari deposito sebesar Rp.78,50 triliun $(58,39 \%)$, tabungan sebesar 40,84 triliun $(30,38 \%)$ dan giro sebesar 15,09 triliun (11,22\%) sedangkan penyaluran dana masih didominasi piutang murabahah sebesar Rp. 80,95 triliun $(59,71 \%)$, pembiayaan musharakah sebesar Rp. 25,21 triliun (18,59\%), pembiayaan mudharabah sebesar Rp.11,44 triliun $(8,44 \%)$ dan piutang Qard sebesar Rp.11,19 triliun ( $8,25 \%)$.

Beberapa karakteristik perbankan syari' ah antara lain : bebas riba, pelayanan kepada kepentingan publik dan merealisasikan sasaran sosio-ekonomi Islam, bersifat universal yaitu gabungan dari bank komersial dan bank investasi, melakukan evaluasi yang lebih berhati-hati terhadap permohonan pembiayaan yang berorientasi pada penyertaan modal, penerapan bagi hasil cenderung mempererat hubungan antara bank syariah dan pengusaha dan membantu bank mengatasi kesulitan likuiditasnya dengan memanfaatkan instrumen pasar uang antarbank syari' ah dan instrumen bank sentral berbasis syariah. Adapun pengawasan perbankan Islam mencakup dua hal yaitu pengawasan dari aspek keuangan, kepatuhan pada perbankan secara umum, dan prinsip kehati-hatian bank. Dan yang kedua pengawasan dalam kegiatan operasional bank. (Soemitra, 2009:67).

Dalam pelaksanaan bank syariah menurut Syukri Iska (2012:58) terbagimenjadi empat model: 1) Menggunakan sistem perbankan syari'ah, 2) Mempunyai dua-sistem sebagaimana yang dilakukan di negara Malaysia beroperasi secara bersama-sama dengan perbankan konvensional, seperti yang terjadi di negara Indonesia. 3) Mempunyai sistem convensional plus, lembaga perbankan pada dasarnya konvensional dengan beberapa lembaga banknya yang beroperasi secara syariah, Indonesia juga masuk kategori conventional plus. 4) hanya menggunakan sistem perbankan konvensional meski mayoritas berpenduduk muslim seperti negara Afganistan, Iraq, Libya, dan Yaman.

Berbagai model pelaksanaan perbankan syariah di dunia menjadi referensi untuk mengetahui lebih jauh bagaimana model yang tepat dan sesuai dengan aturan pendirian perbankan syariah. Secara operasional masih diperbolehkan bersama-sama dengan perbankan konvensional namun yang menjadi syarat utama pendirian perbankan syariah adalah perbankan yang bebas riba.

Sejauh ini praktik perbankan syari' ah di Indonesia senantiasa konsisten dengan meningkatkan investasi dalam pembiayaan yang berbasis pada kontrak mudharabah dan musharakah. (Ismal, 2011: 6)

Tujuan utama didirikannya perbankan syariah menurut Arie Mooduto (2012:6669) antara lain : 1) Menghilangkan praktek ribawi dalam segala kegiatan perbankan dan memastikan semua transaksi perbankan berdasarkan aturan-aturan dalam fiqh Islam. 2) Mewujudkan distribusi pendapatan dan menciptakan keadilan dalam kegiatan perekonomian, karena selama ini sistem ekonomi yang berkembang di dunia belum mampu menyelesaikan berbagai masalah ekonomi masyarakat yaitu harta kekayaan belum terdistribusi secara merata, dan 
rakyat tidak merasakan keadilan dan kenyamanan dalam menjalankan kegiatan ekonomi, masih banyak terjadi praktek aktivitas ekonomi yang bersifat grarar, maysir, ribawi dan spekulasi. 3) Mewujudkan pengembangan pembangunan ekonomi. Dengan menerapkan ekonomi syariah mampu mensejahterakan perekonomian rakyat dan mencapai falah di dunia dan di akhirat.

Pengelolaan dana bank syariah juga memiliki tujuan antara lain memperoleh keuntungan yang optimal, menyediakan aktiva cair (aset tetap) dan kas yang memadai, menyimpan cadangan, mengelola aktivitas lembaga ekonomi dengan kebijakan yang sesuai bagi seseorang yang berlaku sebagai pemelihara dana-dana orang lain, dan memenuhi keperluan pembiayaan masyarakat. Bank syari' ah berdiriuntuk menjalankan fungsi utama yaitu lembaga keuangan bagi para nasabah dan masyarakat. Maka perbankan syariah harus mampu mengelola dana secara optimal. Kekayaan bank syariah dalam bentuk antara lain aktiva produktif yaitu pembiayaan untuk nasabah serta penempatan dana di bank yang menghasilkan pendapatan, dan kekayaan yang tidak menghasilkan yaitu kas dan inventaris (harta tetap). Sedangkan modal bank syariah berasal dari modal sendiri, cadangan dan hibah, infaq atau shadaqah, simpanan dari pihak lain, dan pendapatan usaha keuangan bank syariah berupa bagi hasil atau margin atas mark up dari pembiayaan yang diberikan dan biaya administrasi serta jasa tabungan bank syariah yang terdapat di bank. (Iska, 2012:111)

Mekanisme bagi hasil dalam perbankan syariah terdiri dari dua bentuk, yaitu profit sharing (bagi untung bersih), perhitungannya didasarkan pada hasil bersih dari keseluruhan pendapatan setelah dikeluarkan segala biaya yang dikeluarkan untuk memperoleh pendapatan. Dan bagi hasil bentuk revenue sharing (bagi pendapatan), perhitungan didasarkan pada keseluruhan pendapatan yang diterima sebelum dikurangi biaya-biaya yang telah dikeluarkan untuk memperoleh pendapatan tersebut.

\section{Aplikasi Mudharabah dalam Perbankan Syari'ah di Indonesia}

Secara sederhana aplikasi mudharabah dalam perbankan syari' ah adalah digambarkan sebagai berikut:

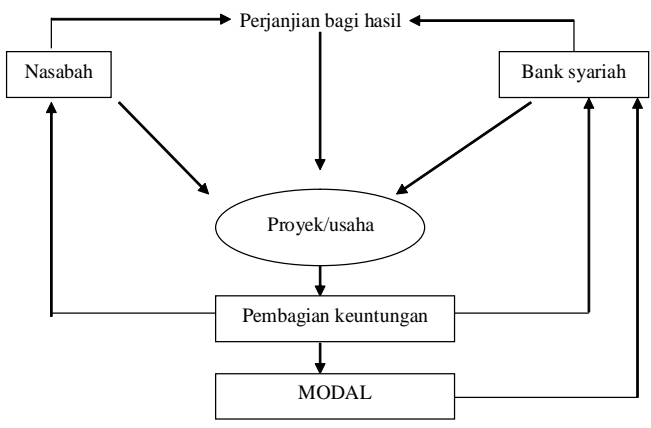

Sumber: Antonio dalam Haidar (2011: 74)

Gambar 1: Aplikasi mudaharabah

Praktek mudharabah dalam perbankan syariah selama ini melibatkan dua pihak antara pemilik modal dengan pengelola, atau pada awalnya terjadi investasi langsung antara shahibul mal sebagai surplus unit dengan mudharib sebagai defisit unit. Seiring perkembangan zaman, prkatek ini berubah dari investasi langsung menjadi investasi tidak langsung atau indirect financing dengan melibatkan lembaga perantara yaitu perbankan yang mempertemukan pemilik modal dengan pengelola.

Dalam investasitidak langsung menurut Adiwarman A. Karim (2011: 211) pihak perbankan menerima dana dari shahibul mal dalam bentuk dana pihak ketiga sebagai sumber dananya. Dana yang disalurkan ke 
Aplikasi Mudharabah dalamPerbankan Syariah di Indonesia (Sri Abidah Suryaningsih)

Tabel 1. Neraca bank syari' ah

\begin{tabular}{lc}
$\begin{array}{l}\text { Aktiva penyaluran dana (financing and } \\
\text { investment) }\end{array}$ & Pasiva sumber dana (funding) \\
\hline Non-earning assets: & Current liabilities \\
• Kas & \\
- Giro pada BI & Dana pihak ketiga : \\
\hline Earning assets: & - Giro wadiah \\
- Surat berharga & - Tabungan mudharabah \\
- Pembiayaan: & \\
1. Murabahah & \\
2. Ijarah & \\
3. IMBT & \\
5. Mudharabah & \\
5. Musyarakah &
\end{tabular}

Stokholder's equity

pihak perbankan syariah dapat berbentuk tabungan atau simpanan deposito mudharabah dengan jangka waktu yang bervariasi. Kemudian dana yang sudah terkumpul disalurkan kembali oleh pihak bank ke dalam bentuk pembiayaan-pembiayaan yang menghasilkan atau earning assets. Keuntungan dari penyaluran pembiayaan ini yang akan dibagihasilkan antara bank dengan pemilik modal, sehingga neraca suatu bank syariah akan tampak pada tabel 1.

Praktik pembiayaan mudharabah di perbankan syariah Indonesia mengalami sedikit perbedaan dengan konsep klasik, hal ini dapat dilihat pada tabel 2. Penerapan mudharabah pada perbankan syariah Indonesia juga terdapat beberapa kendala antara lain; 1) kesulitan menarik kembali dana apabila terjadi wan prestasi, 2) kesulitan perhitungan keuntungan / bagi hasil karena cicilan pengembalian dana, dan 3) tidak boleh ada jaminan. (Ascarya, 2011 : 220). Dengan memperhatikan beberapa kendala tersebut diupayakan adanya keseriusan dari pihak bank untuk menjelaskan secara detail tentang operasional pembiayaan dengan akad mudharabah.

Berdasarkan hasil penelitian terdahulu yang dilakukan oleh Arianto (2011) menyebutkan bahwa ada beberapa upaya untuk mengoptimalkan praktik mudharabah pada bank syariah antara lain adalah: pertama, kesinambungan dan transparansi informasi terhadap usaha yang akan dijalankan. Informasi usaha dan pasar adalah sesuatu yang sangat penting dan berharga dalam setiap usaha. Oleh karena itu langkah ini bisa dimaksimalkan melalui database yang aktual, rinci, dan faktual, sambil terus mencari dan menemukan format usaha yang sesuai dengan iklim usaha tersebut. Kedua, pengembangan industri-industri kecil yang dibina langsung oleh bank syariah. Industri ini benar-benar milik rakyat, prospektif, dan dikelola dengan amanah. Ketiga, Membuat aturan dan regulasi yang tepat, terstandarisasi, dan sesuai dengan prinsip syariah.

Namun, pada kenyataannya produk Mudharabah dalam perbankan syariah belum terlalu diminati masyarakat, karena kurangnya pemahaman dan pengenalan masyarakat mengenai perbankan syariah. Dalam perjalanan usahanya, bank syariah tidak bisa memberikan kontribusi yang maksimal untuk mendukung kemajuan sektor riil, khususnya UMKM. Hal ini terjadi karena pembiayaan yang diberikan didominasi oleh pembiayaan non bagi hasil (murabahah dan ijarah). Sebagaimana data yang tersaji sebelumnya bahwa penyaluran dana pada 
Tabel 2. Praktik pembiayaan mudharabah

\begin{tabular}{|c|c|c|}
\hline Karakteristik pokok & Praktik klasik & Praktik di Indonesia \\
\hline Tujuan transaksi & $\begin{array}{l}\text { Investasi dengan pihak lain } \\
\text { (mudharib) }\end{array}$ & $\begin{array}{l}\text { Pembiayaan/penyediaan } \\
\text { fasilitas }\end{array}$ \\
\hline Pengelola usaha & Mudharib & Nasabah (Mudharib) \\
\hline Pembagian hasil & Profit and loss sharing & Revenue sharing \\
\hline $\begin{array}{l}\text { Penentuan nisbah bagi } \\
\text { hasil }\end{array}$ & $\begin{array}{l}\text { Nisbah bagi hasil tetap } \\
\text { selama periode perjanjian }\end{array}$ & $\begin{array}{l}\text { Nisbah bagi hasil dapat } \\
\text { berubah selama periode } \\
\text { perjanjian (multiple sharing } \\
\text { ratio) dan ditetapkan dalam } \\
\text { akad di awal periode } \\
\text { kontrak }\end{array}$ \\
\hline Pembayaran pokok & $\begin{array}{l}\text { Dilakukan satu kali di } \\
\text { akhir periode }\end{array}$ & $\begin{array}{l}\text { - Dilakukan satu kali di } \\
\text { akhir periode, atau } \\
\text { - Diangsur }\end{array}$ \\
\hline Pembayaran bagi hasil & $\begin{array}{l}\text { Dilakukan satu kali di } \\
\text { akhir periode }\end{array}$ & Di angsur \\
\hline Profit rate & $\begin{array}{l}\text { Di hitung satu kali diakhir } \\
\text { periode atas dasar } 100 \% \\
\text { nilai penempatan dana } \\
\text { investor sejak awal periode } \\
\text { perjanjian }\end{array}$ & $\begin{array}{l}\text { Dihitung atas dasar dana } \\
\text { awal yang masih (dan } \\
\text { dianggap) digunakan oleh } \\
\text { nasabah }\end{array}$ \\
\hline Dalam hal terjadi kerugian & & $\begin{array}{l}\text { Unk satu kali angsuran } \\
\text { pokok: } \\
\text { - } \quad \text { bagi hasil dibayar } \\
\text { periodik sesuai dengan } \\
\text { periode angsuran pokok } \\
\text { dan profit rate dihitung } \\
\text { dari jumlah nominal } \\
\text { bagi hasil per dana awal } \\
100 \% \text {, atau } \\
\text { - bagi hasil dibayar } \\
\text { periodik sesuai dengan } \\
\text { periode angsuran pokok } \\
\text { dan profit rate dihitung } \\
\text { dari jumlah nominal } \\
\text { dari bagi hasil yang di } \\
\text { discount karena } \\
\text { menurunnya share dana } \\
\text { bank dalam usaha } \\
\text { nasabah }\end{array}$ \\
\hline Kolateral & Tanpa jaminan & Dengan jaminan \\
\hline
\end{tabular}

Sumber : Buchari dalam Ascarya (2011:220)

tahun 2012-2013 masih didominasi piutang murabahah sebesar Rp. 80,95 triliun $(59,71)$ sedangkan pembiayaan mudharabah sebesar Rp.11,44 triliun (8,44\%).
Padahal menurut Irfan Syauqi Beik dalam (Arianto, 2011) tingginya porsi pembiaayaan berbasis bagi hasil mempunyai beberapa keunggulan, yaitu: 1) Pembiayaan 
Aplikasi Mudharabah dalamPerbankan Syariah di Indonesia (Sri Abidah Suryaningsih)

mudharabah akan menggerakkan sektor rill karena pembiayaaan ini bersifat produktif yakni disalurkan untuk kebutuhan investasi dan modal kerja. Jika investasi di sektor riil meningkat tentunya akan menciptakan kesempatan kerja baru sehingga dapat mengurangi pengangguran sekaligus meningkatkan pendapatan masyarakat. 2) Nasabah akan memiliki dua pilihan, apakah akan mendepositokan dananya pada bank syariah atau bank konvensional. Nasabah akan membandingkan antara expected rate of return yang ditawarkan bank syariah dengan tingkat suku bunga bank konvensional. Di mana selama ini, kecenderungannya rate of return bank syariah lebih tinggidaripada suku bunga bank konvensional. Dengan demikian diharapkan akan menjadi pendorong peningkatan jumlah nasabah di bank syariah. 3) Peningkatan persentase pembiayaan bagi hasil akan mendorong tumbuhnya pengusaha atau investor yang berani mengambil keputusan bisnis yang berisiko. Pada akhirnya akan berkembang berbagai inovasi baru yang akan meningkatkan daya saing bank syariah. 4) Pola pembiayaan mudharabah adalah pola pembiayaan berbasis produktif yang memberikan nilai tambah bagi perekonomian dan sektor riil sehingga kemungkinan terjadinya krisis keuangan akan dapat dikurangi.

Dengan pemahaman yang menyeluruh terhadap akad mudharabah pada perbankan syari'ah diharapkan meningkatkan kepercayaan masyarakat akan perbankan syariah dalam mendukung distribusi pendapatan, dan mampu memberdayakan sekaligus memberdayakan perkonomian rakyat.

\section{Penutup}

Akad mudharabah dalam konsep fiqih muamalah terjadijika ada pihak shahibul mal atau pemilik modal, ada mudharib atau pengelola, ada obyek yang dikerjakan, dan ada kesepakatan nisbah antara pihak pemilik modal dengan pengelola.

Perbankan syari' ah memiliki ciri-ciri sebagai berikut bebas riba, pelayanan kepada kepentingan publik dan merealisasikan sasaran sosio-ekonomi Islam, bersifat universal, dan penerapan bagi hasil tanpa adanya unsur pemaksaan.

Sedangkan aplikasi mudharabah dalam perbankan syariah di Indonesia memiliki karakteristik sebagai berikut: tujuan transaksi untuk pembiayaan atau penyediaan fasilitas, pengelola usaha adalah nasabah atau mudharib, pembagian hasil mengacu pada konsep revenue sharing, dan penentuan nisbah bagi hasil dapat berubah selama periode perjanjian dan ditetapkan pada akad di awal periode kontrak.

\section{DAFTAR PUSTAKA}

Arianto, Nugroho, A.D. 2011. Peranan AlMudharabah Sebagai Salah Satu Produk Perbankan Syari'ah dalam Upaya Mengentaskan Kemiskinan di Indonesia, Jurnal Ekonomi \& Pendidikan, Vol. 8 No. 2, November 2011.

Ascarya. 2011. Akad \& Produk Bank Syari'ah. Raja Grafindo Persada. Jakarta.

Bank Indonesia. 2013. Outlook Perbankan Syari'ah Tahun 2013. http:// www.bi.go.id.

Gerrard, Philip, Cunningham, Barton. 1997.

Islamic Banking: a Study in Singapore. 
International Journal of Bank Marketing. 15/6(1997) 204-2016, MCB University Press.

Haidar, Ali, dkk. 2011. Pendidikan Agama Islam. Unesa University Press.

Hulam, Taufiqul. 2010. Jaminan Dalam Transaksi Akad Mudharabah Pada Perbankan Syariah. Mimbar Hukum. Volume 22 Nomor 3, Oktober 2010.

Iska, Syukri. 2012. Sistem Perbankan Syari'ah di Indonesia dalam Perspektif Fikih Ekonomi. Fajar Media Press. Yogyakarta.

Ismal, Rifki. 2011. The Indonesian Islamic Banking Theory and Practices. Gramata Publishing. Jakarta.

Karim, Adiwarman A. 2011. Bank Islam Analisis Fiqh dan Keuangan. Rajagrafindo Persada. Jakarta.

Kasmir. 2013. Bank dan Lembaga Keuangan lainnya. Rajagrafindo Persada. Jakarta.

Mardani. 2012. Fiqh Ekonomi Syariah. Kencana Prenada Media Group. Jakarta.

Shihab, Quraish. 2007. Wawasan AlQur'an. Mizan. Jakarta.

Soemitra, Andri. 2009. Bank \& Lembaga Keuangan Syari'ah. Kencana Prenada Media Group. Jakarta. 